${ }^{13}$ Bluglass, R. (1981) Towards a new Mental Health Act: Mental Health Commission for England and Wales. Bulletin of the Royal College of Psychiatrists, 5, 130-2.

${ }^{14}$ Gostin, L. O. (1981) Observations on consent to treatment and review of clinical judgement in psychiatry: a discussion paper. Journal of the Royal Society of Medicine, 74(10), 742-52.

${ }^{19}$ Clare, A. W. (1981) Consent to treatment (Editorial). Journal of the Royal Society of Medicine, 74(11), 787-9.

${ }^{16}$ Rozenberg, J. (1981) The Listener, 19 November.

'DHSS (1981) Mental Health (Amendment) Bill. London: HMSO.
18 - (1981) Reform of Mental Health Legislation. Cmnd 8405. London: HMSO.

${ }^{19}$ Bluglass, R. (1981) Towards a new Mental Health Act: Sections 60 and 65 and the European Commission for Human Rights. Bulletin of the Royal College of Psychiatrists, 5, 151-3.

${ }^{20}$ DHSS (1982) Mental Health (Amendment) Act 1982. London: HMSO.

21_ (1983) Mental Health Act 1983. London: HMSO.

${ }^{22}$ Bluglass, R. (1983) A Guide to the Mental Health Act 1983. London and Edinburgh: Churchill Livingstone.

\title{
The Edinburgh Three-Year Course and M.Phil Degree
}

\author{
R. E. KendelL, Professor of Psychiatry, University of Edinburgh
}

The introduction of the College's Membership Examination in 1971 created a dilemma for the university departments which had previously provided postgraduate teaching for a Diploma in Psychological Medicine. For it was clear that the MRCPsych would soon become a mandatory qualification for anyone wishing to pursue a psychiatric career, at least in this country, and that consequently there would no longer be a useful role for these diplomas. The universities concerned therefore had to choose between letting their diplomas die, or converting them into something other than a basic clinical qualification. The University of Edinburgh, like the Institute of Psychiatry and one or two other departments, decided to replace its DPM with a master's degree (M.Phil) in psychiatry which would be primarily an academic and research qualification, complementing rather than rivalling the College Membership.

The Edinburgh M.Phil came into being in 1972 and has two components: a course of seminars and lectures extending over three years (nine academic terms), and a thesis. The three-year course itself is open to all psychiatric trainees (SHOs, registrars and honorary clinical assistants) on the staff of the Royal Edinburgh Hospital or the six other psychiatric hospitals in SE Scotland within reasonable travelling distance. It consists of a comprehensive programme of lectures and seminars on two afternoons a week $(2.00-5.25 \mathrm{pm})$ for the first five terms and one afternoon a week thereafter. As each term lasts ten weeks the total number of hours of teaching is therefore 420. The first year's teaching is mainly concerned with the basic syndromes and therapies of general psychiatry; the second mainly with research methods and the so-called 'basic sciences' of psychology, neurophysiology, neurochemistry and neuropharmacology; and the third mainly with specialty subjects such as child psychiatry, forensic psychiatry, general hospital psychiatry and the psychiatry of old age. There is also a slow transition from 60-minute lectures in the first year to 90-minute seminars in the third. Dealing with the essentials of clinical psychiatry before the 'basic sciences' is a deliberate policy which we are convinced is educationally sound, despite the protests of some trainees preoccupied with the College's Preliminary Test.

The bulk of the teaching is by members of the university department of psychiatry but there is a substantial contribution from NHS consultants, from the staff of the MRC Epidemiological Studies in Psychiatry and Brain Metabolism Units, and from other departments of the university. Trainees on the course are all formally registered as parttime, supervised postgraduate students of the university and pay standard university fees ( $£ 60$ a year in $1972 / 73$ but now $£ 500$ a year for home and $£ 2370$ a year for overseas students). At the end of their fifth term students have to decide whether or not to enroll formally as candidates for the M.Phil degree. This involves a commitment to writing a thesis on a topic specified at the time and under the supervision of an appropriate member of the academic staff, which consists either of a description of research carried out by the candidate or of a critical review of the literature on that topic. This thesis can be submitted in the ninth term, or at any time during the following fifteen months, i.e. up to four years after first starting the course.

Teaching starts in October each year. There are usually 20-30 trainees in the first year class, 15-25 in the second and $10-20$ in the third, a total of 50-70 overall. Over half are from the Royal Edinburgh Hospital itself, including 10-15 clinical assistants from overseas. The remainder come from other psychiatric hospitals in the region. The Health Boards pay their trainees' fees on their behalf and the clinical tutors in the various hospitals arrange for them to be free of clinical commitments on teaching afternoons. The first intake of students was in October 1972, so the first registrations to take the M.Phil were in April 1974. The first candidates actually to obtain the degree did so in June 1976 and since then $34 \mathrm{M}$.Phils have been awarded, an average of between five and six from each intake. Usually about half the second year students register as candidates for the M.Phil, but on average only half of these actually submit a thesis at 
the end of the day. There is no pressure on trainees to become M.Phil candidates. Indeed, those who-either on the basis of a short answer/MCQ exam at the end of the third term or their clinical tutors' reports-look as though they are going to have difficulty passing the College Membership are actively discouraged from registering. But an attempt is made to persuade trainees on the course that the degree provides a valuable opportunity for them to gain some supervised experience of clinical research in the course of their training.

So far, every thesis submitted has been a description of the candidate's own research rather than a critical review of the literature, mainly because we have tried to convince prospective candidates that planning and carrying out one's own research is a more valuable educational experience. Each thesis is read by an internal and an external examiner, the latter being first Sir Denis Hill, then Professor D. Goldberg and now Professor G. Russell. The candidate has to defend his thesis at a viva voce examination and the examiners have - a choice of four recommendations to the Faculty: to pass the candidate; to require the candidate to resubmit the thesis after making a few relatively minor alterations; to require the candidate to resubmit the thesis, and have a further viva, after making major changes; and to fail them. Since 1976 only two candidates have failed and only one has had to resubmit his thesis after major changes. The majority have been awarded the degree, either immediately or after making minor changes in their thesis, in approximately equal numbers. Most theses have been based on clinical studies of various kinds, often making use of data from the Edinburgh Psychiatric Case Register. One or two involved pharmacological research on laboratory animals. About half were subsequently published in a psychiatric journal, most commonly the British Journal of Psychiatry.

In trying to judge the success of this postgraduate training programme it is important to realize that it serves two distinct purposes. For half our trainees it is primarily a course of lectures and seminars to prepare them for the College Membership Examination, though they would probably recognize some wider educational objectives as well. Viewed in this limited perspective it is fairly successful, even though it is not unknown for those who have attended the course to fail the Membership. At all events the course is popular, particularly the first year's teaching.

The second, and from the university department's point of view the more important objective, is to encourage as many trainee psychiatrists as possible to gain some research experience, and if possible to attract a few into research careers. Success in this respect has been more modest, even though the number of M.Phil theses completed during the last eight years probably equals the number completed in all other university departments combined, including the Institute of Psychiatry. Many trainees never attempt the M.Phil. Some have already started their psychiatric training elsewhere and are unlikely to attend the course for the full three years, others are women with families who realize that they cannot take on additional commitments. Overseas students are often on scholarships of limited duration and decide, rightly, that they must devote all their, energies to obtaining the College Membership.

Of those who do register to take the degree, many never get seriously started. Sometimes their original plans prove impracticable, usually because they had not been properly thought out and piloted in the first place. Or they quickly become daunted by the magnitude of the task they have undertaken and give up. Only a minority of the more able trainees have sufficient energy and self-confidence to make a serious start before they have obtained their College Membership. This means that, contrary to our original intentions, most candidates do not really get down to their research until they have finished the course itself and become senior registrars, which in turn means that those who fail to obtain a senior registrar post locally have usually not made sufficient progress before they move elsewhere for it to be practicable for them to persevere. However, once candidates for the degree have started collecting data seriously they almost always do persevere and get their results written up and their thesis submitted.

Is it all worthwhile? The successful candidate is usually in no doubt that it was, though some would never have started had they realized at the beginning how much work would be involved. Even if this first piece of research is also their last they feel that it was a valuable experience, that they are now better able to assess the papers they read in the journals, and that they will be better teachers and even better clinicians as a result. From the university department's point of view it is gratifying to think that ten or twelve of the theses submitted over these past eight years have not only been excellent pieces of research but also valuable contributions to the literature. On the other hand, a great deal of time is spent advising and supervising registrars who never achieve anything. In the past we have been reluctant to provide candidates with ready made ideas, believing that most people are only likely to be excited by, and be prepared to devote a lot of time to, testing their own ideas. With hindsight this was probably a mistake, for most registrars lack the experience and judgement to know which questions are worth asking, or which can be tackled effectively in the limited time available, and end up getting disillusioned by, for example, their inability to prove that dynamic psychotherapy is effective or that anorexia nervosa is caused by pathological parental attitudes. So from now on we will be more willing to provide prospective candidates with outline plans for modest projects of our devising. We hope that in future the rising calibre of our recruits will result in more being prepared to commit themselves to taking an M.Phil. But we also fear that the rising standard of the College's Membership Examination, and the anxieties this engenders, will make registrars even more reluctant than they are already to think seriously about research until the exam is safely under their belt. 